\title{
The labyrinth of life-styles
}

\author{
Wim Heijs · Marleen Carton · Jos Smeets · Angelique van Gemert
}

Received: 3 March 2008/Accepted: 14 April 2009/Published online: 22 April 2009

(C) The Author(s) 2009. This article is published with open access at Springerlink.com

\begin{abstract}
The increasing complexity of multi-cultural society has given rise to the thought that traditional (demographic and socio-economic) variables are no longer sufficient to substantiate policy development and planning in the housing sector. The concept of life-style is presumed to add to the description and prediction of the demand side, thus enabling housing strategies that are consistent with more dynamic and differentiated preferences. The usefulness of life-styles for policy development was studied in a literature review, in particular of research in the Netherlands. The study shows that the current significance of the concept is doubtful for various reasons: the indefiniteness of life-styles; the static and simplified view of society that is often presented, which is partly caused by the methods used; the uncertain relation to types of residential environment; and the unproven necessity of using life-styles alongside or as a substitute for more traditional variables. Recommendations are offered for future research on this subject.
\end{abstract}

Keywords Demand side $\cdot$ Housing $\cdot$ Life-style $\cdot$ Planning $\cdot$ Policy research

\section{Introduction}

In recent decades, society has become increasingly complex in a social and cultural sense. Probably as a result, residential preferences have become more differentiated and dynamic. A common idea among local governments is that traditional, mainly economic and demographic, variables no longer suffice as a basis for policy and planning in the housing sector. There seems to be a need for alternative procedures to match supply and demand.

W. Heijs $(\bowtie) \cdot$ M. Carton $\cdot$ J. Smeets

Real Estate Management and Development, Department of Architecture, Building and Planning, Eindhoven University of Technology, P.O. Box 513, 5600 MB Eindhoven, The Netherlands e-mail: w.j.m.heijs@bwk.tue.nl

J. Smeets

e-mail: j.j.a.m.smeets@bwk.tue.nl

A. van Gemert

Policy Research Division Municipality of Eindhoven, Eindhoven, The Netherlands 
The concept of life-styles might to a certain extent fulfill this need by adding to a better description and prediction of the demand and of relations with the supply side (Floor and van Kempen 1994; Hooimeijer 1994; De Jong 1996; van Diepen and Musterd 2001).

The concept of life-styles is fashionable. Originally, as a scientific term, it had a limited number of different, fairly well delineated meanings in the disciplines in which it was used. But recently, as a popular and widely used subject, a true labyrinth of definitions, methods and functions has emerged. Following a request by the municipality of Eindhoven, the current usefulness and added value of the concept of life-styles for policy and planning was studied in a literature review, in particular of housing research in the Netherlands (Heijs et al. 2005). After a brief outline of the origins and an overview of the ideas on life-styles in housing research, the significance of the concept is judged from this literature using the following criteria: (1) the availability of a definition suitable for policy and planning; (2) the validity of the underlying assumptions and methodology, and the realism of the subsequent results; and (3) the necessity of using life-styles along with or instead of traditional variables.

\section{A brief overview of the roots}

The scientific origin of life-style is diverse. The main roots are in sociology, psychology, geography, economics and marketing. In sociology, life-styles are mostly viewed as a means of expressing taste and a mechanism to regulate social interaction. They take the form of behavioral patterns that are strongly related to consumption. At the start of the twentieth century, life-styles were used by Veblen, Simmel and Weber to describe social stratification, i.e., to distinguish between social classes or status-groups based on cultural and economic resources (Dangschat and Blasius 1994; van Diepen and Arnoldus 2003; Miles 2001). Later, they were regarded more often as a representation of individual choice and less as a group characteristic. Individuals can belong to more than one life-style group depending on the subject matter, and life-styles can be more flexible over time (Bourdieu 1979; Ganzeboom 1988; Giddens 1991; Sobel 1983). This corresponds to the increased importance in present society of individual conditions compared to group membership or group coherence.

In psychology, the consideration of life-styles is dispersed. The concept was first used by Adler (1933) in psychoanalysis to denote the totality of motives, traits, interests and values that is unique to a person and that guides behavior. Then, it was left untouched for a long period. In the 1990s, life-style was scrutinized in applied social psychology as a means to reduce energy use (Breemhaar et al. 1995). Certain life-styles (or preferred patterns of behavior and routines) may cause a higher energy use. Measures to reduce this might be accepted more easily if they are in line with these life-styles. Some authors assume that lifestyles possess both a latent structure (knowledge, attitudes) and a manifest structure (overt behavior; e.g., Vlek in Paauw et al. 1994). And in this field of study life-styles can be highly specific to certain domains, e.g., to heating or to washing clothes (Breemhaar et al. 1995). The concept also plays a role in economic psychology. Poiesz and van Raaij (2002) view life-style as the totality of activities, interests and opinions together with preferred products and services. It is the result of choices regarding possessions, social contacts, achievement (e.g., career), exploration (new products) and ecology (e.g., transportation). Life-styles can be studied by exploring values and goals that are related to these aspects.

In social geography and economics, life-styles concern the ways people spend their limited amounts of time and money in everyday life (Arentze and Timmermans 2000). 
Such behavior is determined by opportunities and constraints in resources, cooperation and authority (Chapin 1974; Cullen and Godson 1975; Hägerstrand 1970). These points of view have exerted a strong influence on later perspectives on the relation between life-styles and the built environment.

In marketing many life-style typologies have been developed to classify market segments and target groups. Formerly, demographic, geographic or social variables were used but societal trends (e.g., the differentiation of households and larger budgets) caused a need for additional methods (González and Bello 2002; Holt 1997). In 1963, Lazer introduced life-style as an alternative (Tikkanen 2004). It was defined as a characteristic way of life of a group or market segment. Several measurement strategies were conceived, like AIO (Attitudes, Interests and Opinions on a range of topics should give an idea of the spending of time and money) and geo-demographic segmentation methods (e.g., Pinpoint Analysis and ACORN: A Classification Of Residential Neighborhoods). These were criticized for their lack of a theoretical basis and the seemingly arbitrary way of selecting variables (Bushman 1982; Lancaster and Massingham 1993). In reaction to this criticism, approaches emerged that claimed to integrate existing theories (mainly from sociology and the psychology of personality). A famous example is VALS (Values And Lifestyle Segmentation) by Mitchell (1983). In Nine American Lifestyles he regards activities, interests and opinions as symptoms of a psychological state guiding consumption. Therefore, this type of classification is termed psychographic (Holt 1997). The names of the groups give an impression of their members (for example, "I-am-Me's" or "Integrated"). Similar procedures underlie newer typologies, for example those of the Dutch commercial bureaus Motivaction and Smart Agent Company.

\section{Life-styles in housing research: three perspectives}

According to Lööv and Miegel (1990), there are various phenomena that are labeled lifestyles, and they propose a terminology to distinguish between them. Patterns of behavior or psychological features that characterize cultures should be called ways of life (e.g., the American way of life). Patterns in existing groups are life forms. Examples are the social classes in sociology and certain (immigrant) groups' social life in relation to their preferred urban areas in studies by the Chicago School of Urban Research (e.g., Wirth 1928, 1938; Gans 1968). And patterns that are identified first and then coupled with group characteristics and provided with suitable group names are life-styles. The remaining part of this article is about the last type because this is the main form in current housing research. The next question is which patterns are regarded as indicative of life-styles in this area of interest. The literature offers three perspectives on life-style composition and definition.

A relatively small number of authors take the view that life-styles are manifest by nature, composed of consistent and specific behavioral patterns in dwelling, work, leisure and family life, similar to the more recent sociological and geographical angles. They are used as predictors of residential preferences (Brouwer 1998; Driessen and Beerenboom in Ketelaar 1994; De Jong 1996; Reijndorp et al. 1997).

A second perspective is that life-styles are latent and consist of variables such as values, norms, taste, social identity, attitudes, preferences or intentions (e.g., related to housing or to the spending of time or money). These latent patterns can also be used as predictors of residential preferences. In addition, authors in this group generally state that similar life-styles relate to similar residential likings and that a certain homogeneity of life-styles in a matching residential situation may contribute to satisfaction because it facilitates 
psychological appropriation and prevents social problems (Bootsma 1995; Grunfeld in Meij-van Bruggen 1980; Meij-van Bruggen 1980; Versantvoort 2000; de Wijs-Mulkens 1999).

Most publications portray a mixed image of life-styles, with manifest (behavioral) as well as latent (psychological) aspects. The ingredients of a life-style vary: a pattern of overt roles and psychological predispositions for these roles (Michelson and Reed in Meij-van Bruggen 1980); a pattern in consumption and the attitudes towards life (Bastiaansen 1997); a pattern in cultural preferences and activities (Reijndorp et al. 1997) or, on the other hand, functional behavior (van der Land and Machielse 2002); a consistent set of preferences and behavior regarding work, family, dwelling, leisure and consumption (Pinkster and van Kempen 2002); or a totality of thoughts, behavior and preferences related to economic, social and cultural capital (Nio, in Cortie et al. 2003). Others (mainly commercial agencies like Smart Agent Company and Motivaction) employ an even larger array of manifest and latent variables and also add structural attributes (e.g., family size, marital status, education, possessions, time-spending, social interaction, personality types, norms and values) to detect life-styles in cluster analyzes (Hagen 2001; Nijhuis and Schoemaker 2002; de Rooij and Wallagh 2000). The intention is mostly to identify and predict the nature and size of market segments for planning.

\section{Evaluation of the (added) value of life-styles}

In light of the various studies, the labyrinth of life-styles becomes visible. In order to answer the question regarding the possible added value of life-styles for policy and planning, a further analysis was performed of the definitions, methods and results of existing research using the criteria named in Sect. 1 (a suitable definition, the validity of assumptions and methodology and the realism of results, and the need for life-styles). This analysis shows a number of predicaments that are embedded in these categories.

\subsection{Definitions}

Because the concept of life-styles has a mixed origin, it is natural that there are multiple definitions. However, many are so vague that it is unclear how life-styles are to be conceived of. First, their position in the causal chain is ambiguous: life-styles are described alternately as a cause (independent variable), a consequence (dependent) or both (intermediate); and as a manifest, a latent or a mixed characteristic, each of which can play an independent or a dependent part. In a number of publications this is left an open question and the terms used (expressions, roles, orientations or positions) do not clarify the meaning. Even if behavior (manifest) or preferences (latent) are mentioned, one is not sure that this really is what was intended: latent factors (emotions or cognitions) are sometimes seen as a part of behavior (Meij-van Bruggen 1980).

Second, life-styles are indefinite with regard to the elements they cover. There is a wide variety of behavior (such as choice, acquisition, use, consumption), behavioral domains (dwelling, work, leisure, transportation, household, etcetera) and factors that influence behavior (intentions, preferences, values or structural variables). But a reasoned selection is rare and theoretical models that can guide this process are mostly absent. The choice of ingredients often seems to be dictated by the situation at hand and ranges from quite limited (e.g., locational preferences) to very broad (with all sorts of behavior and dispositions; van Diepen and Arnoldus 2003; Pinkster and van Kempen 2002). 
And third, the scale of life-styles is indefinite. The unit of analysis can be the individual, but also households or subcultures. In a spatial sense, they can apply to neighborhoods, districts, cities or larger regions. And the level of specification of the objects of behavior or behavioral dispositions may be low (location, leisure) or high (details of dwellings). Because the scale is generally not elucidated or reasoned, it is possible that conclusions are drawn on the wrong level (e.g., individual answers are considered indicators of the lifestyle of a household, even though there may be different life-styles in a single family).

Such definitions are not useful for an operationalization in research or policy. On the whole, it is unclear which factors belong to life-styles, which are antecedent (for predicting life-styles), which are consequent (to be predicted from life-styles), and which are a part of the context (and should possibly be controlled). As a result, there is a risk of circularity when predicting certain consequences of a life-style that are somehow already a part of it (examples can be found in Reijndorp et al. 1997; and in Pinkster and van Kempen 2002). In addition, indefinite definitions detract from the possibility to distinguish between life-styles and related concepts, such as identity or culture.

\subsection{Validity and realism}

Research within all three perspectives, in particular within the third view (i.e., the commercial cluster analyzes), produces many different life-style groups, ranging between four and twelve and with a wide variety in character (with labels such as yuppies, anarchists, hyper-mobiles, dynamic individualists, quiet luxury, home-loving, settled idealists or tolerant socializers). The validity and realism of such classifications of target groups has been criticized. Do the alleged members, for instance, recognize themselves as such and do they see other groups as different? This has not been tested. Second, the classifications show no borderline cases or cases belonging to more than one group, which is unusual considering the many criteria that are used. It is uncertain what happens with less than perfect respondents, but it seems that sometimes procrustean methods are employed. The fact that the analyzes of commercial agencies practically always result in the same dimensions also points in that direction. Based on the literature, it is plausible that certain individuals do not fit exactly into a group and that some may show characteristics of several life-styles (Bell 1958; Ganzeboom 1988; Lööv and Miegel 1990). Third, there are methodological issues: the analyzes seem elusive, the selection of criteria and the choice of dimensions are not accounted for and there are no tests of fit of the model.

In some latent views of life-styles it is presumed that preferences or actual choices can be predicted from values or emotions. Most social-psychological models, however, show that these relations are weakened by several intervening factors (e.g., social context, attitudes, intentions, control, etcetera). ${ }^{1}$ And the contention of commercial agencies that emotions are going to be more important is not substantiated by their research designs, which measure values (and many other variables) but not emotions.

\footnotetext{
${ }^{1}$ An established example is the Theory of Planned Behavior (Ajzen 1991, 2001). Briefly, the model states that behavior results from intentions and existing possibilities to act. Intentions stem from attitudes (preferences), subjective norms and perceived control regarding the (object of) behavior. The latter three factors are, in their turn, based on the evaluation of possible outcomes, the motivation to comply to norms and estimates of the effects of behavior (so-called beliefs). Beliefs follow from cognition, affect (emotions) and (general) values or goals in life. Personal characteristics (structural, psychological, physical, socio-cultural) and environmental features (physical, social, organizational) can influence variables and their relations. Hence, if two variables are farther apart (as with emotions or values and behavior), the chance of an acceptable prediction is smaller.
} 
A more general topic pertains to the dynamic nature of life-styles. They are influenced by the social and the physical environment, they change in the course of life and can be altered by societal and technological developments and by previous choices. Change in life-style or migration from one group to another, however, is not provided for in most results. This causes a paradox: in order to get a grasp on a dynamic society, life-style research is looking for static groups. Together with the fact that the samples tend to be small and selective (van Diepen and Arnoldus 2003; Ouwehand 2001; Pinkster and van Kempen 2002), this leads to the conclusion that the investigations produce rather simplified and stationary images of reality, which can probably not be generalized to larger groups or future policy.

\subsection{Necessity}

The necessity of incorporating life-styles in policy and planning in the housing sector is based on the assumption that traditional variables are no longer sufficient for the prediction of residential preferences because of the increased socio-cultural complexity of society. Life-styles may provide new information. Several other reasons are mentioned: e.g., the growing competition on the housing market, in which case using life-styles might be an advantage; the increasing role of emotions; and the notion that converging certain lifestyles in certain types of residential environment may improve satisfaction and prevent conflicts that could arise from having different life-styles in one locality (van der Wouden and Kullberg 2002).

The literature, however, does not furnish definite proof of the notion that traditional variables are insufficient, nor of the supposition that life-styles perform better (Ganzeboom 1988; Pinkster and van Kempen 2002). Research on these matters is scarce (comparative studies seem to be non-existent) and results are contradictory. Some publications reveal that life-style groups differ regarding preferred locations, e.g., the city center, the outskirts or rural (Brouwer 1998; Reijndorp et al. 1997) while other results show that prediction did not improve significantly (Driessen and Beerenboom in Ketelaar 1994; De Jong 1996; Pinkster and van Kempen 2002). The reasoning that the increased societal complexity requires other predictors sounds plausible but it might not be true. It is possible that the additional variance can be explained by the usual variables (Pinkster and van Kempen 2002).

Replacing traditional variables with life-styles (as opposed to adding life-styles) is not recommended on theoretical grounds. Manifest or mixed conceptions of life-styles that incorporate present behavior on the housing market rely on 'revealed preferences' (a future choice is predictable from the current one). These can be invalid, as they are also influenced by other factors such as the availability of preferred types of housing, work, life cycle or family matters (Bootsma 1995; Versantvoort 2000). Likewise, latent or mixed models that take 'stated preferences' as a basis (a future choice is predictable from the preferences one has) might be faulty because they can express temporary wants or ideals that cannot be realized. Revealed preferences are, so to speak, biased by constraints, stated preferences by expected opportunities and both are dependent on structural variables. The latter variables are also needed for the control of contextual influences and spurious correlations. Life-style research should, therefore, incorporate opportunities, constraints and structural variables and not intend to substitute them.

According to Hagen (2001), a life-style approach becomes more important because the competition on the housing market is increasing and emotions play a more significant role. He uses a clustering of values together with other variables (not emotions as was 
mentioned previously) to arrive at life-style groups that are presumed to be fairly homogeneous with regard to housing preferences. The housing market is undeniably becoming demand-oriented but thus far there is relatively little competition among suppliers, at least in social housing, which is a large sector in the Netherlands. In addition, it is unlikely that emotions will surpass rational considerations (e.g., financial and functional). Therefore, the proposed need to use life-styles for these goals is somewhat exaggerated. It is possible that this will change, but then there is no point in assessing contemporary life-styles because they might be different in the future.

In a number of publications, a correspondence is found (or suggested) between lifestyles and types of residental environment. Bastiaansen (1997) states that life-styles serve as a guide for social interaction and that his 11 groups can therefore be used to develop new residential areas that fulfill more needs and prevent annoyance. De Rooij and Wallagh (2000) depict five groups that planners should take into account in the development of a new district in Amsterdam. A majority of authors, however, conclude that life-styles are less useful in this respect because there is no direct relation with types of residential environment. The choice of a location is dependent on other factors as well (e.g., on functional grounds) and types of residential environment can accommodate different lifestyles (Bertholet 1992; van Diepen and Arnoldus 2003; van Diepen and Musterd 2001; van der Land and Machielse 2002; Nio 2002; Nio in Cortie et al. 2003; Ouwehand 2001; Pinkster and van Kempen 2002; Reijndorp et al. 1997; Reijndorp et al. 1998; van der Wouden and Kullberg 2002). Residential environments (or habitats) develop naturally and the intention of controlling their development might be an illusion. The best way to access control is possibly by facilitating preferred activities of certain groups. The contention that different life-styles are to be avoided because they may cause conflicts is too simple. From a psychological point of view, people usually value a certain variety and research has shown a preference for mixed settings. Besides, it is questionable whether life-style research can detect possible conflicts in advance, so that it is difficult to establish when and where to intervene.

\section{Conclusions and recommendations}

This literature review reveals serious doubts regarding the added value of the concept of life-styles for policy and planning in the housing sector. As yet, the labyrinth of life-styles has no easy way out and it should perhaps not be entered at all. In summary, the main hesitations relate to the problematical definition and operationalization in research and practice due to the indefiniteness of the subject, doubts regarding the validity and realism of both methods and outcomes (by displaying a simplified and static view of an increasingly dynamic and complex society), and the unproven necessity of using life-styles for predicting choice behavior beyond traditional variables and for matching residential preferences and environments. These objections are not easily dealt with.

Starting with the latter argument, supplementary research seems to be required to establish whether the proposed limitations of traditional variables actually exist. These problems may be less significant than expected or be of another nature. It is quite possible that residential preferences in our multi-cultural society do not show much additional variance or that traditional variables are adequate for explaining this variance. It is also not unlikely that the influences of competition, emotions and expected conflicts in heterogeneous environments on choice behavior are overrated. If additional research, nevertheless, 
shows that traditional variables are inadequate, regular social and cultural characteristics can be added as extra variables. Combined variables such as life-styles should only be used as a final resort because real information can be lost in the grouping process, false information may be produced and classifying residents in a limited set of segregated clusters may produce artificial results when forcing less typical cases into groups they do not really belong to.

If it is concluded that life-styles are the proper way to proceed, the other problems and uncertainties mentioned above have to be eliminated. A shared definition and a guiding theoretical model that suits this definition are recommended as a basis for the selection of predictors and methods (for an example see footnote 1). The definition and the methodology should reflect the complexity and dynamics of the real world. Multivariate methods must incorporate tests of fit as a control and the procedures must be clear, e.g., with respect to the grounds for selecting dimensions, the control of context variables and the treatment of borderline cases. And classifications with an option that members can migrate to another group or share features of more groups will probably be more representative of reality.

Open Access This article is distributed under the terms of the Creative Commons Attribution Noncommercial License which permits any noncommercial use, distribution, and reproduction in any medium, provided the original author(s) and source are credited.

\section{References}

Adler, A. (1933). Der Sinn des Lebens. Wenen: Leiptzig Passer.

Ajzen, I. (1991). The theory of planned behavior. Organizational Behavior and Human Decision Processes, $50,179-211$.

Ajzen, I. (2001). Nature and operation of attitudes. Annual Reviews of Psychology, 52, 27-58.

Arentze, T., \& Timmermans, H. (2000). Albatross. A learning based transportation oriented simulation system. Eindhoven: Technische Universiteit, EIRASS.

Bastiaansen, I. (1997). Leefstijlen als basis voor het nieuwe wonen. In J. Broess \& C. Grijzen (Eds.), Brabant ongemonteerd (pp. 5-20). Den Bosch: Projectburo Brabant 2050.

Bell, W. (1958). Social choice, life styles and suburban residence. In W. Dobriner (Ed.), The suburban community (pp. 225-247). New York: G.P. Putnam's Sons.

Bertholet, P. (1992). Stedelijke Woonmilieus en Stedelijke Woonvoorkeuren. Den Haag: VROM.

Bootsma, H. (1995). The influence of a work oriented lifestyle on residential location choice of couples. The Netherlands Journal of Housing and the Built Environment, 10, 45-63.

Bourdieu, P. (1979). La Distinction; Critique Sociale du Jugement. Paris: Editions de Minuit.

Breemhaar, B., van Gool, W., Ester, P., \& Midden, C. (1995). Levensstijl en Huishoudelijke Energieconsumptie. Tilburg/Eindhoven: IVA/TUE.

Brouwer, J. (1998). Leefstijlen en Woonmilieus. Delft: ABF.

Bushman, F. (1982). Systematic life styles for new product segmentation. Academy of Marketing Science Journal, 10, 377-394.

Chapin, F. (1974). Human activity patterns in the city. New York: Wiley.

Cortie, C., Droogleever Fortuijn, J., \& Wagenaar, M. (2003). Stad en Land. Over Bewoners en Woonmilieus. Amsterdam: Aksant.

Cullen, I., \& Godson, V. (1975). Urban networks: The structure of activity patterns. Progress in Planning, 4, $1-96$.

Dangschat, J., \& Blasius, J. (1994). Lebensstile in den Städten: Konzepte und Methoden. Opladen: Leske und Budrich.

de Jong, F. (1996). Woonvoorkeuronderzoek: Theorie, Empirie en Relevantie voor de Praktijk. Woonconsument en Woningkwaliteit 5. Delft: Technische Universiteit Delft, Faculteit Bouwkunde.

de Rooij, L., \& Wallagh, G. (2000). Wie Woont er aan de Zuidas? Leefstijlen en Woonarrangementen voor de Zuidas. Amsterdam: Blauwhoed/Eurowoningen, MAB, Woonstichting De Key/De Principaal. 
de Wijs-Mulkens, E. (1999). Wonen op Stand. Lifestyles en Landschappen van de Culturele en Economische elite. Amsterdam: het Spinhuis.

Floor, H., \& van Kempen, R. (1994). Wonen op Maat: Een Onderzoek naar de Voorkeuren en Motieven van Woonconsumenten en te Verwachten Ontwikkelingen daarin. Deel 1: Theoretische Uitgangspunten en Probleemstelling. Utrecht: Faculteit Ruimtelijke Wetenschappen, Universiteit Utrecht.

Gans, H. (1968). Urbanism and suburbanism as ways of life. In R. Pahl (Ed.), Readings in urban sociology (pp. 95-114). London: Pergamon.

Ganzeboom, H. (1988). Leefstijlen in Nederland: Een verkennende studie. Den Haag: Sociaal Cultureel Planbureau.

Giddens, A. (1991). Modernity and self-identity: Self and society in the late modern age. Stanford: University Press.

González, A., \& Bello, L. (2002). The construct "lifestyle" in market segmentation: The behaviour of tourist consumers. European Journal of Marketing, 36, 51-85.

Hagen, G. (2001). Motivational profiling in de woningmarkt. Tijdschrift voor de Volkshuisvesting, 3, 6-11.

Hägerstrand, T. (1970). What about people in regional science? Regional Science Association Papers, 24, 721.

Heijs, W., Carton, M., Smeets, J., \& van Gemert, A. (2005). Labyrint van leefstijlen [Labyrinth of lifestyles]. Eindhoven: Technische Universiteit. Cahier 07 (www.eplus.nl/images/cahier07leefstijlen.pdf).

Holt, D. (1997). Poststructuralist lifestyle analysis: Conceptualizing the social patterning of consumption in postmodernity. Journal of Consumer Research, 23, 326-350.

Hooimeijer, P. (1994). Hoe meet je woonwensen? Methodologische haken en ogen. In I. Smid \& H. Priemus (Eds.), Bewonerspreferenties: Richtsnoer voor Investeringen in Nieuwbouw en de Woningvoorraad (pp. 3-12). Delft: Delftse Universitaire Pers.

Ketelaar, J. (1994). Het Woonmilieu op Begrip Gebracht. Bouwstenen 27. Eindhoven: Faculteit Bouwkunde, Technische Universiteit Eindhoven.

Lancaster, G., \& Massingham, L. (1993). Essentials of marketing. London: McGraw-Hill.

Lööv, T., \& Miegel, F. (1990). The notion of lifestyle: Some theoretical contributions. The Nordicom Review, 1, 21-31.

Meij-van Bruggen, R. (1980). Wonen op je eigen manier: De toenemende betekenis van leef- en woonstijl. Intermediair, 16, 19-27.

Miles, S. (2001). Social theory in the real world. London: Sage Publications.

Mitchell, A. (1983). The nine American lifestyles. New York: Warner.

Nijhuis, M., \& Schoemaker, R. (2002). Normen, waarden en woonbelevingsgroepen: Consumentenonderzoek van Motivaction. Stedebouw \& Ruimtelijke Ordening, 83, 43-45.

Nio, I. (2002). Van levenswijzen tot lifestyles: Over de bruikbaarheid van leefstijlen voor de ruimtelijke ordening. Stedebouw \& Ruimtelijke Ordening, 83, 6-10.

Ouwehand, A. (2001). Een wijk is geen auto. Tijdschrift voor de Volkshuisvesting, 7, 10-15.

Paauw, K., Perrels, A., \& van Veenendaal, A. (1994). Leefstijl en Energie: Van Intentie naar Actie. Petten: ECN.

Pinkster, F., \& van Kempen, R. (2002). Leefstijlen en Woonmilieuvoorkeuren. Utrecht: Urban and Regional Research Centre, Universiteit Utrecht.

Poiesz, T., \& van Raaij, F. (2002). Synergetische marketing. Amsterdam: Pearson Education Benelux.

Reijndorp, A., Kompier, V., \& de Haas, L. (1997). Leefstijlen. Wonen in de 21ste Eeuw. Rotterdam: NAi.

Reijndorp, A., Kompier, V., Nio, I., \& Truijens, B. (1998). Buitenwijk. Stedelijkheid op Afstand. Rotterdam: NAi.

Sobel, M. (1983). Lifestyle differentiation and stratification in contemporary US society. In D. Treiman \& R. Robinson (Eds.), Research in social stratification and mobility (pp. 115-144). New York: JAI Press Inc.

Tikkanen, H. (2004). Marketing milestones 1950-2000. Retrieved August 2, 2004, from Institute of Strategy and International Business, University of Technology Helsinki Web site: www.tuta.hut.fi/studies/ Courses_and_Schedules/Isib/TU-91.108/kurssimateriaali/030926_TU91108_Tikkanen_Marketing_ Milestones.pdf.

van der Land, M., \& Machielse, K. (2002). Faciliteren van leefstijlen: Duurzame woonmilieus in Flevoland. Stedebouw \& Ruimtelijke Ordening, 83, 28-33.

van der Wouden, R., \& Kullberg, J. (2002). Stijloefeningen: Leefstijlen in onderzoek en praktijk. Stedebouw \& Ruimtelijke Ordening, 83, 10-20.

van Diepen, A., \& Arnoldus, M. (2003). De Woonvraag in de Vraaggestuurde Markt. Amsterdam: DGW/ NETHUR.

van Diepen, A., \& Musterd, S. (2001). Stedelijke Leefstijlen en Woonmilieus in Amsterdam. Amsterdam: Amsterdam Study Centre for the Metropolitan Environment. 
Versantvoort, M. (2000). Analysing labour supply in a lifestyle perspective. Rotterdam: Tinbergen Institute, Erasmus University Rotterdam.

Wirth, L. (1928). The ghetto. Chicago: University of Chicago Press.

Wirth, L. (1938). Urbanism as a way of life. American Journal of Sociology, 44, 1-24. 